\title{
High-Risk Neuroblastoma
}

National Cancer Institute

\section{Source}

National Cancer Institute. High-Risk Neuroblastoma. NCI Thesaurus. Code C150281.

Neuroblastoma usually presenting with metastatic disease and MYCN gene amplifications. 